\title{
PERANAN PRE DAN POST ISCHEMIC CONDITIONING SEBAGAI PENCEGAHAN CEDERA REPERFUSI
}

\section{Hamzah Muhammad Zein}

Fakultas Kedokteran, Universitas Andalas Sumatera Barat, Indonesia

Email: hamzah13017@gmail.com

\begin{abstract}
Abstrak
Reperfusi pneada jaringan iskemik sering mengakibatkan proses patofisiologi, seperti gangguan endotelium pada arteriol, peradangan dan ekstravasasi protein plasma di venula. Ada berbagai mekanisme yang menyebabkan cedera reperfusi. Salah satu mekanismenya adalah dengan diproduksinya radikal oksigen sehingga dapat melepaskan mediator inflamasi. Manifestasi klinis yang timbul juga beragam, salah satu contohnya, pada jantung, dapat terjadi myocardial stunning. Penulisan literature review ini bertujuan untuk memahami peranan pre dan post ischemic conditioning sebagai pencegahan cedera reperfusi sehingga dapat mengarahkan ke asesmen dan pemberian terapi yang tepat kepada pasien. Secara epidemiologi, cukup banyak didapatkan kejadian cedera reperfusi yang tidak mendapatkan manajemen yang memadai, sehingga diperlukan pembahasan peranan pre dan post ischemic conditioning dari berbagai literatur. Literature review ini dilakukan pada April 2019 dengan mengambil sumber data dari berbagai sumber buku dan jurnal medis. Referensi yang diambil dari original research dan buku. Ada berbagai studi yang mengungkapkan terapi atau tindakan untuk mencegah cedera reperfusi, yaitu ischemic conditioning. Fokus terapi atau tindakan untuk mencegah cedera reperfusi berdasarkan mekanisme-mekanisme yang terjadi pada cedera reperfusi. Mekanisme ischemic conditioning mencegah cedera reperfusi dengan cara mencegah apoptosis, onkosis, dan meningkatkan antioksidan. Mekanisme ischemic conditioning ini berawal dari stimulus dan aktivasi terhadap sinyal transduksi kardioproteksi. Sinyal ini memiliki efek akhir untuk menghambat pembukaan mPTP, sehingga efek cedera reperfusi bisa dikurangi.
\end{abstract}

Kata Kunci: cedera reperfusi; terapi; post ischemic conditioning
Abstract
Reperfusion of ischemic tissue often results in pathophysiological processes, such as endothelium disruption in arterioles, inflammation and extravasation of plasma proteins in venules. There are various mechanisms that cause reperfusion injury. One of the mechanisms is the production of oxygen radicals so that they can release inflammatory mediators. The clinical manifestations that arise are also diverse, one example is in the heart, myocardial stunning can occur. Writing this literature review aims to understand the role of pre and post ischemic conditioning as prevention of reperfusion injury so that it can lead to assessment and appropriate therapy for patients. Epidemiologically, there are quite a lot of cases of reperfusion injuries that do not get adequate management, so it is necessary to discuss the role of

$\begin{array}{ll}\text { How to cite: } & \text { Zein. H. M., (2021) Peranan Pre dan Post Ischemic Conditioning Sebagai Pencegahan Cedera } \\ & \text { Reperfusi, Syntax Idea, 3(10), https://doi.org/10.36418/syntax-idea.v3i10.1512 } \\ \text { E-ISSN: } & \text { 2684-883X } \\ \text { Published by: } & \text { Ridwan Institute }\end{array}$


pre and post ischemic conditioning from various literatures. This literature review was conducted in April 2019 by taking data sources from various sources of books and medical journals. There are various studies that reveal therapies or actions to prevent reperfusion injuries, namely ischemic conditioning. The focus of therapy or action to prevent reperfusion injury is based on the mechanisms that occur in reperfusion injury. The mechanism of ischemic conditioning prevents reperfusion injury by preventing apoptosis, oncosis, and increasing antioxidants. This ischemic conditioning mechanism begins with stimulation and activation of cardioprotective signal transduction. This signal has the final effect of inhibiting mPTP opening, so that the effect of reperfusion injury can be reduced.

Keywords: reperfusion injury, therapy; post ischemic conditioning

\section{Received: 2021-09-22; Accepted: 2021-10-05; Published: 2021-10-20}

\section{Pendahuluan}

Cedera reperfusi, yang bisa disebut juga dengan cedera reperfusi iskemia atau cedera reoksigenasi, adalah kerusakan jaringan yang disebabkan ketika aliran darah kembali ke jaringan, setelah periode iskemia atau kekurangan oksigen (anoksia atau hipoksia). Oksigen dan nutrisi dari darah yang berkurang selama periode iskemik menciptakan suatu kondisi yang berpotensi berbahaya bila terjadi reperfusi, yaitu dapat menghasilkan peradangan dan kerusakan oksidatif (Sanada, Komuro, Kitakaze, \& Physiology, 2011)

Miokardium dapat terjadi kerusakan atau cedera secara reversibel setelah terjadi iskemik dan direperfusi. Didukung juga dari penelitian Bolli, dkk, bahwa kerusakan atau cedera pada miokardium tersebut disebabkan oleh zat radikal bebas yang dihasilkan setelah reperfusi (Touboul et al., 2015).

Telah banyak dilakukan penelitian untuk mencari metode pencegahan terjadinya cedera reperfusi ini. Metode yang dikenal dengan pre dan post ischemic conditioning. Ischemic preconditioning telah diakui sebagai salah satu mekanisme yang baik untuk melindungi dari cedera iskemik miokard dengan cara menginduksi periode iskemik singkat sebelum dilakukan reperfusi. Pada penelitian hewan percobaan dan manusia, periode singkat iskemia telah terbukti melindungi jantung dari lebih banyak episode iskemia yang berkepanjangan, mengurangi ukuran infark, dan tingkat keparahan aritmia yang diinduksi reperfusi, dan mencegah disfungsi sel endotel (Chahine, Makhlouf, Duca, Martiny, \& Chahine, 2014).

Literature review ini lebih membahas secara lengkap tentang pencegahan dan terapi dari cedera reperfusi. Metode lainnya dengan post ischemic conditioning, yaitu dengan menginduksi kondisi iskemik singkat berulang yang reversibel selama awal periode reperfusi setelah periode iskemik yang lama untuk mengurangi cedera reperfusi. Ischemic postconditioning telah dilaporkan dapat mengurangi ukuran infark pada pasien dengan IMA-EST yang menjalani IKP dalam uji klinis (Hahn et al., 2013).

Beberapa studi, telah terbukti pre dan post ischemic conditioning dengan berbagai macam mekanismenya dapat memproteksi dari efek buruk cedera reperfusi. Ischemic 
conditioning tersebut telah banyak diterapkan pada pasien yang menjalani terapi reperfusi (Alizadeh Pahavani et al., 2020).

\section{Metode Penelitian}

Penulisan literature review ini bertujuan untuk memahami peranan pre dan post ischemic conditioning sebagai pencegahan cedera reperfusi sehingga dapat mengarahkan ke asesmen dan pemberian terapi yang tepat kepada pasien. Secara epidemiologi, cukup banyak didapatkan kejadian cedera reperfusi yang tidak mendapatkan manajemen yang memadai, sehingga diperlukan pembahasan peranan pre dan post ischemic conditioning dari berbagai literatur. Literature review ini dilakukan pada April 2019 dengan mengambil sumber data dari berbagai sumber buku dan jurnal medis. Pemilihan referensi dipilih berupa original research, maupun buku yang membahas pencegahan dan terapi cedera reperfusi.

\section{Hasil dan Pembahasan}

\section{Ischemic preconditioning}

\section{a. Definisi}

Ischemic preconditioning didefinisikan sebagai proses iskemia periode pendek untuk membuat miokard lebih resisten terhadap efek iskemik dengan periode yang lebih panjang. Ischemic preconditioning awalnya didefinisikan proses iskemia jangka pendek untuk membatasi ukuran infark. Beberapa peneliti memperluas definisi ini dengan memasukkan juga efek positif dalam pencegahan aritmia dan myocardial stunning (Sanada et al., 2011).

\section{b. Mekanisme Ischemic Preconditiong dalam Pencegahan Cedera Reperfusi}

Istilah ini diperkenalkan untuk pertama kalinya oleh Murry et al, menemukan di penelitian pada binatang dengan model anjing yang mana dengan empat periode berturut-turut oklusi koroner selama 5 menit mampu mengurangi ukuran infark yang disebabkan oleh periode oklusi 40 menit berikutnya sebanyak 75\%. Efek proteksi ischemic preconditioning bersifat sementara dan bertahan selama 2 jam, yang disebut juga dengan ischemic preconditiong awal. Namun, efek proteksi timbul lagi saat 24 jam setelah preconditiong dan bertahan sampai 48 jam. Efek perlindungan yang tertunda ini dimediasi oleh aktivasi gen yang mengkode protein sitoprotektif (Sánchez-Hernández, Torres-Alarcón, GonzálezCortés, \& Peón, 2020).

Ada beberapa mekanisme ischemic preconditiong (IPC) dalam memproteksi suatu sel dari cedera reperfusi dari pencegahan terhadap apoptosis, onkosis, radikal bebas sehingga dapat mengurangi luasnya infark (Sanada et al., 2011).

\section{Ischemic preconditiong dalam Mencegah Apoptosis}

Ischemic preconditiong dapat melindungi kardiomiosit dari apoptosis selama reperfusi. Mekanisme perlindungan dari apoptosis kardiomiosit oleh IPC berawal dari perlindungan mitokondria. Ischemic preconditiong dapat mencegah disfungsi mitokondria yang disebabkan hilangnya aktivitas enzim ketoglutarat dehidrogenase 
pada siklus krebs, masuknya protein Bcl-2 protein sebagai pro- apoptosis ke dalam mitokondria, dan pelepasan sitokrom c ke dalam sitosol. Perlindungan mitokondria oleh IPC ini dimediasi oleh suatu sinyal untuk mencegah pembukaan mPTP (Tomai, Crea, Chiariello, \& Gioffrè, 1999). Sinyal-sinyal ini berlangsung pada mitochondrial KATP (mitoKATP) channel pathway, the phosphatidylinositol 3kinase (PI3K)/ Akt pathway, dan p42/p44 ERK1/2 (Alizadeh Pahavani et al., 2020).

\section{IPC Mencegah Onkosis}

Onkosis adalah suatu proses peningkatan permeabilitas sel membran sebagai salah satu fitur cedera reperfusi miokard. Saat terjadi reperfusi miokard tiba-tiba terjadi peningkatan tekanan mekanik pada membran sarkolemal, terkait dengan reintroduksi aktivitas kontraktilitas. Hal ini dapat mengurangi energi sel dalam jumlah banyak dan berujung pada onkosis (Isik et al., 2015).

Kerapuhan sarkolema adalah penyebab onkosis selama reperfusi. Penghambatan kerapuhan sarkolema selama reperfusi sebagai mekanisme utama kardioproteksi yang dimediasi oleh IPC. Jantung normal mempunyai sarcolemma yang melekat erat pada sarkomer melalui Z-band. Namun, tak lama setelah reperfusi, sarcolemma mengalami kerusakan di Z-band. Kerusakan Z-band ini meningkatkan permeabilitas melalui sarkolema. Oleh karena itu, tekanan fisik yang dipaksakan pada membran ini menyebabkan kerusakan pada Z-band. Terdapat juga zat dystrophin yang dikenal dapat menstabilkan sarkolema terhadap tekanan sehingga dapat mengurangi kerusakan membran. Saat terjadi cedera reperfusi dystrophin ini berkurang, sehingga banyak terjadi kerusakan. Ischemic precondition membuat

dystrophin ini dapat dipertahankan sehingga perlindungan pada membran terjadi (S hah, Yellon, Davidson, \& therapy, 2020).
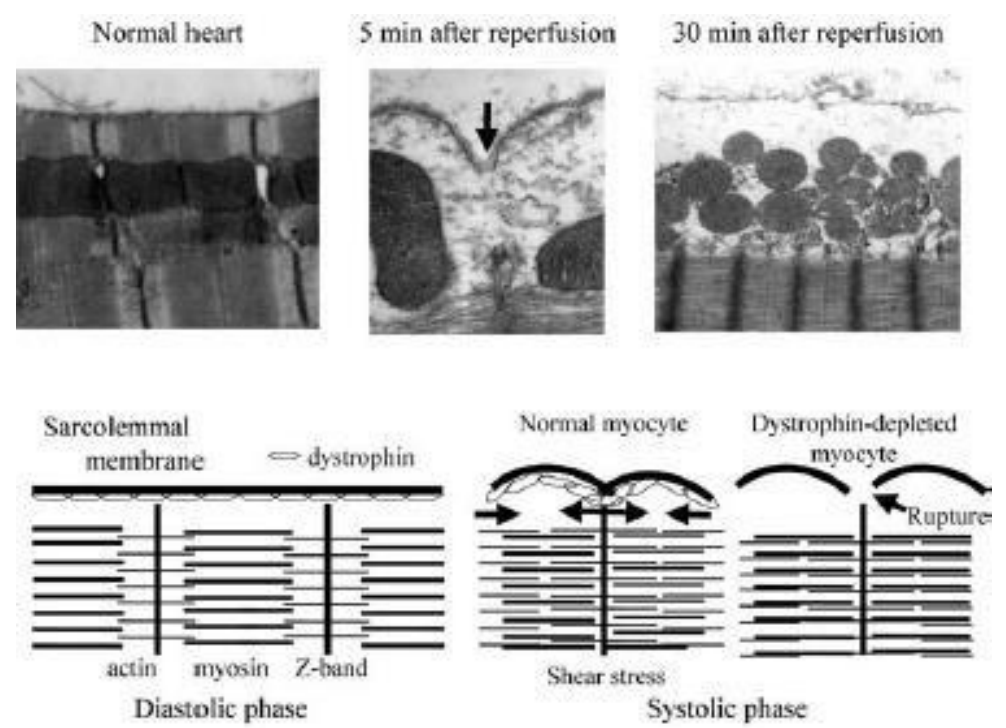

Gambar 1

Proses Onkosis pada Cedera Reperfusi 


\section{IPC dan Saluran Klorida.}

Mekanisme lain perlindungan yang dimediasi oleh IPC adalah penghambatan aktivasi saluran klorida. Saluran klorida memainkan peran penting dalam regulasi volume sel pada pembengkakan sel. Studi dikatakan bahwa regulasi volume sel dapat ditingkatkan oleh IPC melalui aktivasi saluran klorida dan dapat bertanggung jawab untuk sebagian besar perlindungan sarkolema terhadap reperfusi-menginduksi pembengkakan sel masif dengan pecahnya membran sel. Saluran klorida ini tidak hanya mengatur masuknya klorida tetapi juga masuknya superoksida. Penghambatan saluran klorida akan mencegah masuknya superoksida (Hahn et al., 2013).

\section{IPC dan Sistem Pertahanan Antioksidan}

Sistem kardiovaskular terus menerus terpapar pada ROS dan nitrogen reaktif. Oksigen, meskipun penting untuk jaringan kelangsungan hidup, bisa berbahaya bila diproduksi secara berlebihan saat reperfusi. Beberapa kelompok peneliti mengukur ROS pada miokard, tampak peningkatan ROS yang signifikan pada miokard yang mengalami reperfusi. ROS ini memainkan peran penting dalam cedera miokard. Sejumlah sumber ROS telah ditemukan pada saat reperfusi miokardium sebagai infiltrasi leukosit polimorfonuklear (PMN) ke dalam jaringan infark, xanthine oksidase, aktivasi kaskade arachidonate, autoksidasi katekolamin, dan aktivasi dari berbagai NAD $(\mathrm{P}) \mathrm{H}$ oxidases. Akumulasi PMNs di jantung adalah suatu penyebab cedera reperfusi. PMN yang melekat pada endotelium dapat melukai endothelial. Secara mekanis dapat menyebabkan oklusi pada jumlah besar kapiler dan secara kimiawi dengan melepaskan ROS. Pada IPC, terbentuklah NF-B yang dapat memediasi jalur kardioprotektif dalam IPC dengan meningkatkan protein sitoprotektif. NF-B dapat mengurangi ekspresi inflamasi dari sitokin, dengan demikian mengurangi ukuran infark (Özer et al., 2017).

Superoksida bersamaan dengan nitric oxide (NO) menghasilkan peroxynitrite, sebagai mediator cedera miokard selama reperfusi yang lebih kuat. NO dihasilkan oleh nitric oxide synthase (NOS) dengan menggunakan 1-arginin, NADPH, dan oksigen, serta kofaktor tetrahydrobiopterin (BH4). IPC dapat menghambat NOS selama reperfusi dengan menghilangkan ROS (Özer et al., 2017).

Teori lain menyebutkan mekanisme IPC dalam memproteksi jantung dengan memproduksi ROS dalam jumlah kecil sebagai sinyal yang menginduksi proteksi jantung. Salah satu produksi ROS selama IPC adalah xanthine oxidase. Xanthine oksidase dapat diaktifkan selama iskemia dengan peningkatan degradasi adenine nukleotida menjadi hipoksantin, lalu konversi dengan enzim sitosolik xanthine dehydrogenase menjadi xanthine oksidase. Selain itu, NADH oksidase baru-baru ini juga muncul sebagai sumber ROS pada proses IPC. Studi yang dilakukan oleh Bell dan rekan, menunjukkan bahwa NADPH oksidase memainkan peran penting dalam menghasilkan ROS yang bertindak sebagai pemicu dalam transduksi sinyal kardioprotektif di IPC. Transduksi sinyal kardioprotektif ini dengan menghalangi pembukaan mPTP (Alizadeh Pahavani et al., 2020). 


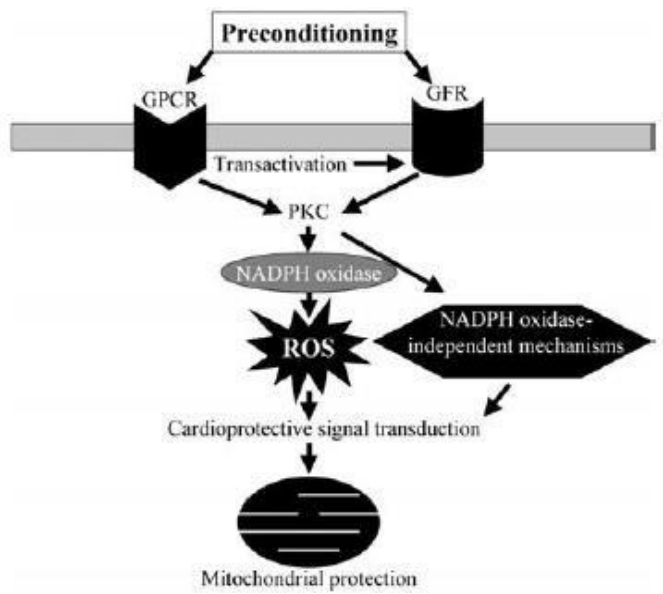

Gambar 2

Hubungan IPC, ROS, dan Proteksi Mitokondria

\section{IPC meningkatkan Angiogenesis dan Mencegah Perluasan dari Infark.}

Kemajuan terbaru telah menunjukkan bahwa miokardium dapat diselamatkan setelah oklusi arteri koroner permanen. Sejauh mana daerah perbatasan miokardium dapat diselamatkan sangat tergantung pada tingkat angiogenesis. IPC telah terbukti menghambat remodeling ventrikel kiri pada model hewan di penelitian karena peningkatan proses angiogenesis. Ischemic preconditiong telah muncul sebagai pendekatan yang menjanjikan untuk terapi angiogenesis (Isik et al., 2015).

Hipoksia terjadi akibat ketidakseimbangan antara persediaan dan konsumsi oksigen. Oklusi arteri koroner penghentian pasokan darah secara tiba-tiba, menyebabkan anoksia atau hipoksia dari miokardium yang terkena. Sirkulasi kolateral berkembang di daerah miokard dengan suplai darah sebagai bentuk angiogenesis. Terbentuknya sirkulasi kolateral membantu menyelamatkan sel-sel endotel dan kardiomiosit dari hipoksia yang menyebabkan kematian, dengan demikian berkontribusi terhadap penghambatan hilangnya massa fungsional miokardium dan kompensasi hipertrofi kardiomiosit. Hipoksia adalah stimulus angiogenesis yang kuat. Hipoksia jaringan mengarahkan tindakan proangiogenik melalui berbagai faktor angiogenik, yang paling menonjol adalah faktor pertumbuhan endotel vaskular(VEGF). Flt-1 (VEGF receptor-1) dan Flk-1 / KDR (VEGF receptor-2) adalah reseptor spesifik endothelium untuk VEGF. Dua faktor angiogenik lainnya, angiopoietin 1 dan 2, telah ditemukan untuk mengatur pematangan yang pembuluh darah baru dari sel endotel yang berkembang biak. Hipoksia meningkatkan level dari VEGF. Studi terbaru menunjukkan bahwa IPC menginduksi VEGF dan meningkatkan kepadatan kapiler sebelumnya infark miokard (Xiaochun, Jianjun, Jianping, \& Medicine, 2013). 


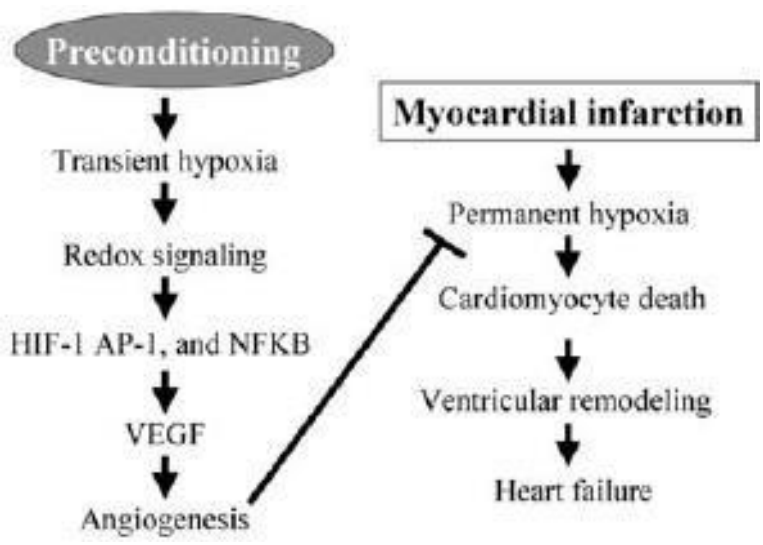

Gambar 3

IPC meningkatkan angiogenesis dan mencegah perluasan dari infark

\section{Ischemic Postconditioning}

Ischemic postconditioning lebih dapat diterapkan secara klinis daripada ischemic preconditioning karena ischemic postconditioning tidak harus diberikan sebelum episode iskemik, tetapi dapat diberikan pada saat reperfusi. Banyak studi mengatakan efek memperkecil ukuran infark dari ischemic postconditioning sama baiknya dengan ischemic preconditioning. Efek kardioprotektif ini dikaitkan dengan peningkatan fungsi endotel, pengurangan superoksida, dan penurunan apoptosis (Isik et al., 2015).

Ischemic postconditioning telah dilaporkan pada penelitian menggunakan binatang dan beberapa penelitian juga meneliti pada manusia. Laskey, dkk melaporkan penelitian terhadap 17 pasien menjalani intervensi koroner perkutan untuk infark miokard akut dengan hasil terdapat aliran darah yang lebih banyak pada pasien dengan jantung yang telah mengalami postconditioning. Saat,dkk menerbitkan studi di mana 30 pasien dirawat karena akan dilakukan tindakan angioplasti koroner untuk infark miokard akut sebagai reperfusi dan dibandingkan antara pasien yang diangioplasti dengan stent saja (kelompok kontrol) dan yang dilakukan protokol ishemic postconditioning setelah reperfusi dengan stenting. Salah satu protokol post conditioning terdiri dari 1 menit reflow diikuti oleh 1 menit inflasi balon angioplasti dan 1 menit deflasi balon. Hal ini dilakukan sebanyak 4 kali berurutan. Area beresiko ditentukan dari LV angiogram. Terdapat hasil ukuran infark miokard 36\% lebih rendah pada kelompok postconditioning. Grade blush, juga lebih baik dikelompok postconditioning (Sanada et al., 2011).

Postconditioning menginduksi ekspresi phospho-Akt dan menimbulkan efek kardioproteksi dengan menghambat pembukaan Mitochondrial permeability transition pore (mPTP) dan membuka saluran mitochondrial potassium ATP (mK $\left.\mathrm{m}_{\text {ATP }}\right)$ (Chahine et al., 2014). 


\section{Remote Ischemic Post Conditioning}

Remote ischemic Post conditioning (RIPC) adalah prosedur medis yang bertujuan untuk mengurangi keparahan cedera iskemik pada organ seperti jantung atau otak, paling umum dalam situasi serangan jantung atau stroke, atau selama prosedur seperti jantung operasi ketika jantung mungkin menderita iskemia sementara selama operasi, dengan memicu perlindungan alami tubuh terhadap cedera jaringan. Cara dari prosedur ini dengan penghentian sementara aliran darah ke anggota tubuh untuk menciptakan iskemia (kekurangan oksigen dan glukosa) dalam jaringan. "Pengondisian" ini mengaktifkan pelindung fisiologi alami tubuh terhadap cedera reperfusi dan kerusakan jaringan yang disebabkan oleh kadar oksigen yang rendah.(Sánchez-Hernández et al., 2020).

RIPC miokard menggunakan otot rangka sebagai stimulus iskemik. Tourniquet atau manset yang diaplikasikan pada anggota badan dapat menyebabkan $R I P C$ tanpa perlunya prosedur invasif. Perlindungan miokard yang diinduksi oleh $R I P C$ terjadi dalam dua fase. Fase awal berlangsung sekitar empat jam, sementara yang fase tertunda dimulai > 24 jam setelah induksi iskemia dan dipertahankan sampai 48 jam. Pada fase awal, terjadi perubahan langsung dalam miokardium dan sirkulasi koroner, dengan peningkatan aliran diastolik dan vasodilatasi koroner. Hal ini dapat mengurangi ukuran infark dan risiko aritmia reperfusi. Mekanisme patofisiologis yang terlibat dalam RIPC adalah masih belum sepenuhnya dipahami, tetapi dapat dibagi menjadi tiga komponen: (i) produksi atau pelepasan efektor dalam jaringan iskemik; (ii) mekanisme komunikasi antara wilayah yang di RIPC dan miokardium;dan (iii) induksi respons kardioprotektif (Hausenloy \& Yellon, 2013).

\section{Mekanisme RIPC pada Tingkat Subseluler}

Pertama, efek dari remote ischemic postconditioning adalah stimulasi reseptor adenosine. Adenosine yang dihasilkan saat iskemia dilepaskan ke sirkulasi pada saat reperfusi. Remote Ischemic postconditioning yang dilakukan setelah iskemia saat reperfusi akan menunda pembuangan adenosine intravaskular dan menimbulkan efek proteksi. Opioid endogen, aktivasi bradikinin reseptor, administrasi eritropoetin, nitric oxide, asetilkolin dan penurunan ekspresi dari tissue factor merupakan mekanisme kardioproteksi remote ischemic postconditioning. Remote ischemic postconditioning juga dapat mengurangi sitokin pro inflamasi seperti TNF- $\alpha$ dan IL-6 serta menurunkan produksi zat oksigen reaktif yang menimbulkan efek kardioproteksi (Fröhlich, Meier, White, Yellon, \& Hausenloy, 2013).

Selanjutnya, saluran mitokondria ATP-sensitive potassium (KATP) terbuka selama iskemia sementara pada otot rangka. Ini adalah hilir PKC di RIPC dan bergantung padanya untuk mereaaktivasi. Agonis protein $G$ memicu kaskade pensinyalan kardioprotektif yang mengaktifkan protein kinase(PKC) dan membuka saluran KAPT mitokondria (Bonow, Mann, Zipes, \& Libby, 2011) 
Hal ini memicu pembukaan saluran KAPT mitokondria melalui aktivasi PKC, yang mendepolarisasi membran mitokondria, sehingga mengurangi penyerapan $\mathrm{Ca}^{2+}$ sebagai efek kardioprotektif. Peningkatan produksi ROS selama postconditioning dapat meningkatkan produksi enzim antioksidan yang melindungi mitokondria dan mengurangi apoptosis. Pentingnya PKC tidak terbatas pada efeknya pada saluran KAPT mitokondria; itu juga bertindak pada mPTP. Pada saat RIPC, PKC membentuk kompleks dengan mPTP sehingga dapat mencegah pembukaan mPTP dan dengan demikian menghambat apoptosis di miosit selama reperfusi (Hall, 2016).

Jalur reperfusion injury survival kinase (RISK) melibatkan jalur p42/p44 ERK1/2 dan PI3K-Akt disebut juga dengan jalur alamiah untuk pertahanan hidup sel karena dapat terstimulasi saat terjadi cedera reperfusi. Aktivasi kinase-kinase tersebut menghambat jalur proapoptosis, menstimulasi eNOS dan mengaktifkan jalur KATP. Jalur PI3-Akt menstimulasi eNOS melalui fosforilasi akan meningkatkan kadar NO, menghambat mPTP dan menekan nekrosis dan apoptosis sel. Remote ischemic postconditioning diketahui mengaktifkan komponen jalur RISK, terutama PI3-Akt (Araszkiewicz, Grygier, Lesiak, \& Grajek, 2013).

Jalur RISK memiliki tiga konsep dasar yaitu (1) aktivasi jangka pendek dari kinase-kinase bersifat protektif, (2) jalur ini harus diaktifkan pada saat awal reperfusi untuk menimbulkan efek kardioproteksi terhadap cedera reperfusi. Jalur RISK diaktifkan pada dua waktu, saat siklus preconditioning (sebelum episode iskemik) yang dikenal sebagai fase "trigger" dan saat fase awal reperfusi ketika mPTP terbuka pada lima belas menit pertama reperfusi, (3) jalur RISK merupakan kaskade sinyal universal untuk kardioproteksi. Setelah 24 jam RIPC, gen terlibat untuk perlindungan terhadap stres oksidatif, seperti Hadhsc, Prdx4, dan Fabp4 diaktifkan, sedangkan gen proinflamasi seperti, Egr-1 dan Dusp 1 dan 6 ditekan (Costa, Fontes-Carvalho, \& Leite-Moreira, 2013). Mekanisme transduksi selanjutnya akan mengaktifkan substans perantara atau jalur yang berhubungan dengan efektor diantaranya mitochondrial permeability transtition pore (mPTP) dan kanal KATP. Selain itu juga efek fisiologis, seperti penyembuhan jaringan asidosis yang mungkin secara independen dari jalur molekuler yang memberikan efek proteksi (Abrams, Telford, \& Rollins, 2014). 


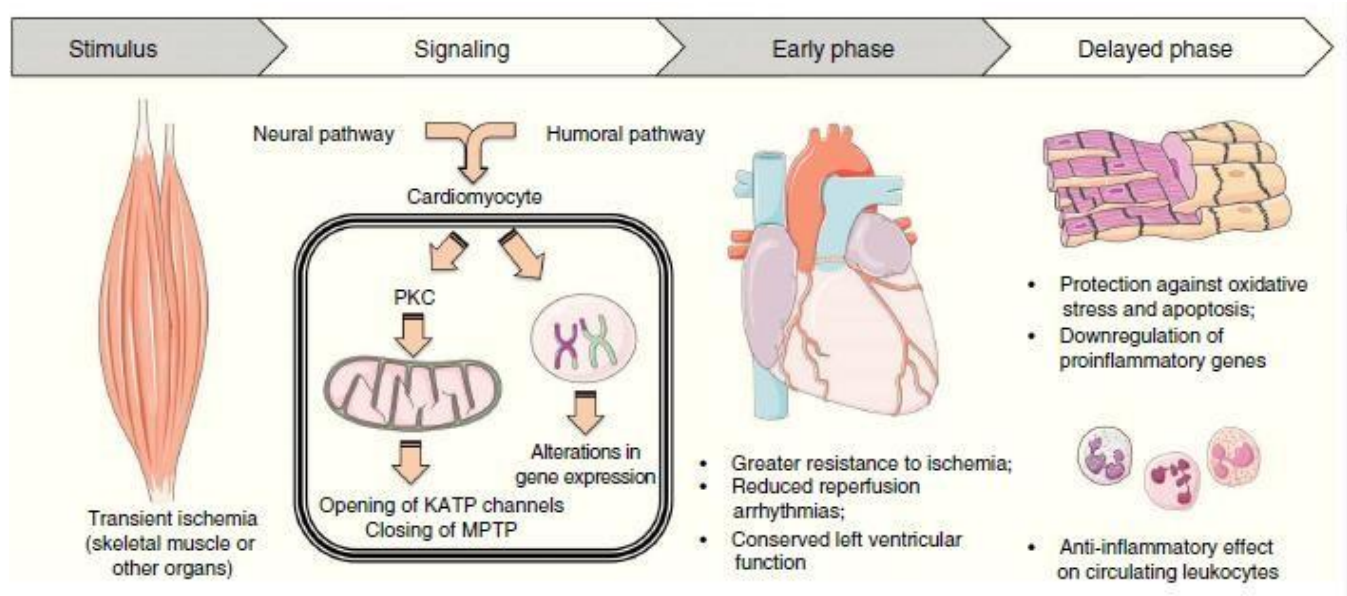

Gambar 4

Proses RIPC untuk mencegah Cedera Reperfusi

Mekanisme kardioprotektif bisa dibagi atas mekanisme fisiologis dan jalur molekuler prosurvival. Keberagaman dan interaksi antara jalur fisiologis dan molekuler yang dipicu oleh remote ischemic postconditioning dapat menjelaskan mengapa pengaruh remote ischemic postconditioning dalam mengurangi injuri reperfusi dibandingkan dengan intervensi yang hanya memicu satu mekanisme atau target (Özer et al., 2017).

\section{Kesimpulan}

Dari penelitian ini hasilnya adalah (1) Cedera reperfusi merupakan suatu kejadian patologis yang serius. Salah satu studi mengatakan insiden cedera reperfusi sebanyak 8 $\%$ yang menyebabkan mortalitas. Banyak mekanisme yang menyebabkan cedara reperfusi yang bisa berujung ke kematian sel. (2.) Berbagai mekanisme yang mencetus cedera reperfusi, yaitu stres oksidatif dari radikal oksigen yang dapat menyebabkan kerusakan membran, kelebihan kalsium saat pengaktifan kembali mitokondria, dan proses peradangan. (3.) Mekanisme ischemic conditioning mencegah cedera reperfusi dengan cara mencegah apoptosis, onkosis, dan meningkatkan antioksidan. Mekanisme ischemic conditioning ini berawal dari stimulus dan aktivasi terhadap sinyal transduksi kardioproteksi. Sinyal ini memiliki efek akhir untuk menghambat pembukaan mPTP, sehingga efek cedera reperfusi bisa dikurangi. 


\section{BIBLIOGRAFI}

Abrams, J., Telford, W. G., \& Rollins, L. J. D. D. (2014). The many roads to cell death: discriminating between apoptosis, necrosis and autophagy. 15, 41. Google Scholar

Alizadeh Pahavani, H., Rajabi, H., Nabiuni, M., Motamedi, P., Khaledi, N., \& Tayanloo, A. J. S. P. (2020). The Effect of Aerobic Exercise with Medium and High Intensity on the Gene Expression of Bax (BCL2 Associated X) and Bcl-2 (B-Cell Lymphoma 2) Markers in Rat Myocard After Ischemic-Reperfusion. 12(45), 31-44. Google Scholar

Araszkiewicz, A., Grygier, M., Lesiak, M., \& Grajek, S. J. P. w. K. I. A. i. I. C. (2013). The impact of ischemia-reperfusion injury on the effectiveness of primary angioplasty in ST-segment elevation myocardial infarction. 9(3), 275.

Bonow, R. O., Mann, D. L., Zipes, D. P., \& Libby, P. (2011). Braunwald's heart disease e-book: A textbook of cardiovascular medicine: Elsevier Health Sciences. Google Scholar

Chahine, N., Makhlouf, H., Duca, L., Martiny, L., \& Chahine, R. J. Z. f. N. C. (2014). Cardioprotective effect of saffron extracts against acute doxorubicin toxicity in isolated rabbit hearts submitted to ischemia-reperfusion injury. 69(11-12), 459470. Google Scholar

Costa, José F., Fontes-Carvalho, Ricardo, \& Leite-Moreira, Adelino F. (2013). Myocardial remote ischemic preconditioning: from pathophysiology to clinical application. Revista Portuguesa de Cardiologia (English Edition), 32(11), 893904. Google Scholar

Fröhlich, G. M., Meier, P., White, S. K., Yellon, D. M., \& Hausenloy, D. J. J. E. h. j. (2013). Myocardial reperfusion injury: looking beyond primary PCI. 34(23), 1714-1722. Google Scholar

Hahn, Joo Yong, Song, Young Bin, Kim, Eun Kyoung, Yu, Cheol Woong, Bae, Jang Whan, Chung, Woo Young, Choi, Seung Hyuk, Choi, Jin Ho, Bae, Jang Ho, \& An, Kyung Joo. (2013). Ischemic postconditioning during primary percutaneous coronary intervention: the effects of postconditioning on myocardial reperfusion in patients with ST-segment elevation myocardial infarction (POST) randomized trial. Circulation, 128(17), 1889-1896. Google Scholar

Hall, John E. (2016). Guyton and Hall Textbook of Medical Physiology, Jordanian Edition E-Book. Elsevier. Google Scholar

Hausenloy, D. J., \& Yellon, D. M. J. T. J. o. c. i. (2013). Myocardial ischemiareperfusion injury: a neglected therapeutic target. 123(1), 92-100. Google Scholar 
Heusch, Gerd. (2015). Molecular basis of cardioprotection: signal transduction in ischemic pre-, post-, and remote conditioning. Circulation Research, 116(4), 674699. Google Scholar

Isik, A., Peker, K., Gursul, C., Sayar, I., Firat, D., Yilmaz, I., \& Demiryilmaz, I. J. I. j. o. s. (2015). The effect of ozone and naringin on intestinal ischemia/reperfusion injury in an experimental model. 21, 38-44. Google Scholar

Özer, A., Erer, D., Oktar, L., Kip, G., Bilge, M., Kavutçu, M., . . Ünal, Y. J. G. M. J. (2017). The Effect of Dexmedetomidine on Ischemia Reperfusion Injury in Myocard of Rat. 29(1). Google Scholar

Sanada, S., Komuro, I., Kitakaze, M. J. A. J. o. P.-H., \& Physiology, C. (2011). Pathophysiology of myocardial reperfusion injury: preconditioning, postconditioning, and translational aspects of protective measures. 301(5), H1723-H1741. Google Scholar

Sánchez-Hernández, C. D., Torres-Alarcón, L. A., González-Cortés, A., \& Peón, A. N. J. M. o. i. (2020). Ischemia/reperfusion injury: pathophysiology, current clinical management, and potential preventive approaches. 2020. Google Scholar

Shah, M., Yellon, D. M., Davidson, S. M. J. C. d., \& therapy. (2020). The role of extracellular DNA and histones in ischaemia-reperfusion injury of the myocardium. 34(1), 123-131. Google Scholar

Touboul, Caroline, Angoulvant, Denis, Mewton, Nathan, Ivanes, Fabrice, Muntean, Danina, Prunier, Fabrice, Ovize, Michel, \& Bejan-Angoulvant, Theodora. (2015). Ischaemic postconditioning reduces infarct size: systematic review and metaanalysis of randomized controlled trials. Archives of Cardiovascular Diseases, 108(1), 39-49. Google Scholar

Xiaochun, F., Jianjun, C., Jianping, W. J. M. J. o. I. T. C., \& Medicine, W. (2013). Effects of Huanglian Jiedu decoction on NF- $\kappa B$ signal transduction pathway of myocardial ischemia-reperfusion injury in rats. 1 .

Copyright holder:

Hamzah Muhammad Zein (2021)

First publication right:

Syntax Idea

This article is licensed under:

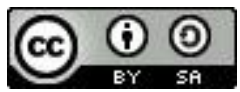

